Article

\title{
Success Factors of National-Scale Forest Restorations in South Korea, Vietnam, and China
}

\author{
Gayoung Choi ${ }^{1}$, Yoonjeong Jeong ${ }^{1}$ and Seong-il Kim ${ }^{1,2, * \mathbb{D}}$ \\ 1 Department of Forest Sciences, Seoul National University, Seoul 08826, Korea; lemian@snu.ac.kr (G.C.); \\ yoonjeong522@snu.ac.kr (Y.J.) \\ 2 Research Institute of Agriculture and Life Sciences, Seoul National University, Seoul 08826, Korea \\ * Correspondence: seongil@snu.ac.kr; Tel.: +82-2-880-4765
}

Received: 22 March 2019; Accepted: 21 June 2019; Published: 25 June 2019

\begin{abstract}
The total global forest area is decreasing significantly, yet stories of successful large-scale forest restoration are still scarce. In the 1980s, when properly designed concepts and methodologies were absent, state-led, large-scale restoration projects in lower-income countries (LICs) in Asia were already successful. These then LICs-South Korea, Vietnam, and China-experienced dramatic forest land use changes driven by different socioeconomic and political developments, from deforestation and forest degradation to reforestation and ecological restoration. This study examines the institutional settings of each country's restoration programs, focusing on the inputs of the external factors, their effects on the relevant action arena, and their payment mechanisms. By conducting critical comparisons between three country cases, we found that the ability of nations that had implemented reforestation programs to restore their forests was often influenced by external variables, which included biophysical conditions, local community attributes, and local, state, and federal rules. The result of this research provides practical implications and contributes to the body of literature comparing restoration cases from Asian countries, which have rarely been investigated.
\end{abstract}

Keywords: deforestation; reforestation; rules; community participation; forestry fund; payment mechanism

\section{Introduction}

According to the Global Forest Resources Assessment 2015 by the Food and Agriculture Organization of the United Nations (FAO) [1], the total global forest area decreased by 129 million hectares (ha) (3.1\%) in the period 1990-2015. The annual rate of decline was approximately $0.13 \%$, but there were significant regional variations. High-income countries (This was determined based on the World Bank's income categories as of July 2013.)(HICs) have gained forest over the last 25 years, while low-income countries (LICs) have lost their forests over the same period [1]. Though there was a decline in net forest loss from 2.9 million ha between 1990 and 2000 to 2.4 million ha between 2010 and 2015 in LICs, the significant gap between HICs and LICs has hardly narrowed [1]. In most LICs, deforestation has been mainly caused by the conversion of forest land to agriculture and livestock areas [1-3]. These land-use changes have resulted in serious environmental problems such as habitat loss, the decreased availability of clean water, and the release of carbon into the atmosphere, and have consequently affected the lives of the world's poorest and most vulnerable communities, whose livelihoods depend on forests [3].

While ambitious climate goals have been presented by countries in the context of the 2020 revision of the Nationally Determined Contributions (NDCs) under the Paris Agreement, many challenges remain. Forest landscape restoration (FLR) has been suggested as a promising nature-based solution to deforestation and degradation. This approach emphasizes regaining the ecological, social, climatic, and 
economic benefits of forests by restoring deforested or degraded lands through sustainable land use practices [3,4]. To date, over 170 million hectares have been pledged for restoration by 58 national and subnational governments and other entities under the Bonn Challenge, supported by the FLR approach.

However, in the 1980s, when FLR and other similar concepts and methodologies were absent, state-led large-scale restoration projects in Asian LICs were already successful. While most LICs were experiencing rapid forest losses in the 1980s, only three countries-South Korea, Vietnam, and China-achieved successes in combating deforestation. Asia was the only region in the world whose forest cover increased in 2010, when China finished its first restoration program.

Since the best practice cases in South Korea, Vietnam, and China achieved what was regarded as almost impossible, many scholars have shown an increasing interest in their logical analysis and political implications. The establishment of relevant laws and policies as well as the commitment of local communities were the common factors that led to the success of these three forest restoration cases. Additionally, these three countries received international attention for developing incentive-based payment mechanisms for environmental policy programs, the potential applicability of which had only been discussed within academic bodies at the time.

Institutions are defined as "enduring regularities of human action in situations are structured by rules, norms, shared strategies, and the physical world. The rules, norms, and shared strategies are constituted and reconstituted by human interaction in frequently occurring or repetitive situations" [5]. Institutions promote positive outcomes by helping actors address the "social dilemma" that arises when individual rational behaviors are aggregated to produce irrational social outcomes [6].

Accordingly, institutional analysis is particularly important at the pre-project or planning stage of research activities or projects, which allows decision making regarding the appropriate institutional setting for the proposed activity [7]. In the forest management context, institutions include all kinds of formal and informal prescriptions-legal documents issued by the central government on forest management, the informal rules allowing state administration at lower levels and enabling relative freedom in interpreting relevant documents, and the collective rules orally shared within a community, for example [8].

In this research, three national-level forest restoration cases from South Korea, Vietnam, and China were selected for analysis. Conducting a comparison through relevant framework, the objectives of the study were as follows: First, we identified similarities and differences in institutional settings that had achieved successful restoration. Second, we examined how the payment mechanisms for forest restoration were introduced in the three countries. The result of this research provides practical implications and contributes to the body of research on comparisons of restoration cases from Asian countries, which have only rarely been investigated.

\section{Materials and Methods}

\subsection{Case Selection}

Three cases were selected for comparison: (1) The First Ten-Year Forest Rehabilitation (TYFR) plan in South Korea, (2) the Five Million Hectare Reforestation Program (5MHRP) in Vietnam, and (3) the Sloping Land Conversion Program (SLCP) in China. For the analysis, geographical scopes were set to cover the countries of interest. The cases spanned from the period when the state-led restoration programs began to when they first ended after achieving success. Two different sources of empirical data were employed: (1) Official documentary sources such as laws, agency policy statements, and legislative and professional society debates; and (2) archival and dependable secondary sources published by international organizations and scientific journals.

These cases, along with incentive-based programs and logging bans aimed at reducing the deforestation of native forests while increasing forest cover, played an important role in forest restoration. The three cases shared many features. First, they involved government-led restoration programs; second, they were characterized by strong state authority during their implementation; and 
third, they shared the same complementary objectives of poverty reduction and rural development. Though South Korea's reforestation policy did not fit the exact definition of a payment mechanism, after reviewing the main forest restoration efforts that were implemented with various incentive programs (including both cash and in-kind payments), it was regarded as a payment scheme in this research.

Before Japanese colonization, South Korea was a densely forested country (per ha $100 \mathrm{~m}^{3}$ ). However, during colonization and the Korean War, forests were destroyed by massive and excessive cutting for fuel and exportation purposes, resulting in a decreasing the per ha volume to about $10 \mathrm{~m}^{3}$ [9]. The Korean government established state-led forest restoration projects in the late 1960s and early 1970s. The government implemented major forestry initiatives which were started by the president and were met with public support [10]. In 1973, the TYFR plan was established. With it, 207,000 hectares of plantation land were created, reaching a total of 643,000 hectares in 1977 [11]. The success of these projects received global attention. Lester Brown, a famous environmentalist, noted in his book that "South Korea is a reforestation model for the world. We can reforest the earth [9]".

Vietnam is a mountainous country with a monsoonal climate; its economy is critically dependent on the watershed services provided by forests, especially in rural uplands where agriculture and hydropower are important sectors [12]. Thus, the value of forests had been strongly promoted by the central government through large-scale projects to reforest millions of hectares of land [13]. The 5MHRP was implemented by the central government, international agencies, and non-governmental organizations based in Vietnam. It aimed to provide incentives and rewards to upland farmers to encourage them to afforest and reforest bare hills, mountains, and other areas [14]. The plan increased the nation-wide forest coverage to $39.5 \%$ of the total land cover in 2010, up from $32 \%$ in 1998 [15]. Additionally, the forest sector was actively involved in employment creation and livelihood improvement for nearly $25 \%$ of the country's population [16].

The Chinese government implemented a logging ban in 1998, sharply curtailing commercial harvesting in the western and northern areas of the country [17]. The SLCP, also known as "Grain for Green" or "Conversion of Cropland to Forests and Grassland," was initiated by the central government in 1999 after a devastating flood in the Yangtze River Basin the previous year. It was the largest land retirement and reforestation program in the developing world, with a total budget of almost CNY 430 billion (USD 45 billion), and it aimed at converting 14.67 million hectares of cropland to forests (4.4 million of which were on land with slopes greater than 25 degrees) by 2010. The program had an additional goal of afforesting a roughly equal area of wasteland by 2010 [18]. The whole project was fully implemented in 2002, after the announcement of advice regarding further improving policy measures for the SLCP as well as regulations for the program. The central government was the chief funding agency for the project, paying local farmers to stop farming and plant trees instead. It compensated them with (1) an annual in-kind subsidy of grain; (2) a cash subsidy; and (3) free saplings provided to the farmer at the beginning of the planting period [19]. Consequently, China gained almost 14 million hectares of forest cover, revealing that about $37 \%$ of its forest lands were planted [20].

\subsection{Analytical Framework}

In this study, inputs included the contextual factors (attributes of the community, physical conditions, and rules-in-use) covering all aspects of the social, cultural, institutional, and physical environment that set the context within which an action situation was found [21]. These created effects on the action arena consisted of actor and action situations that included information availability and cost/benefits to actions and outcomes. The interaction of the two big factors resulted in outcomes of policy implementation.

The constitutional level refers to the processes through which collective choice procedures are defined, including legitimizing and creating all relevant entities involved in collective or operational choice processes [21]. Based on this basic framework, this study focused on the implementation of 
payment mechanisms in each country at the constitutional level. Constitutional choice outcomes affect collective decision-making, which, in-turn, affects activities at an operational-level.

Relevant variables were selected based on previous research. First, the trend of deforestation was regarded as a physical condition. Second, regulatory frameworks were defined as rules-in-use. Third, the project objective and the basis for participation were used as defining attributes of a community. Fourth, an actor was divided into four levels, ranging from international to local. Finally, a payment mechanism was regarded as an action arena in this study. A payment mechanism could also be divided into three different arenas according to its general characteristics, as well as its payment and design features (Table 1).

Table 1. Analytical dimensions and criteria.

\begin{tabular}{|c|c|c|c|}
\hline Dimension. & \multicolumn{2}{|c|}{ Criteria } & Source \\
\hline Physical condition & \multicolumn{2}{|c|}{ - The trends of deforestation } & Modified from [22] \\
\hline Rules in use & \multicolumn{2}{|c|}{$\begin{array}{ll}\text { - } & \text { Regulatory framework } \\
\text { - } & \text { Ownership status and land use }\end{array}$} & Modified from [23] \\
\hline Attributes of community & \multicolumn{2}{|c|}{$\begin{array}{ll}\text { - } & \text { Project objectives } \\
\text { - } & \text { Participation principles and terms }\end{array}$} & Modified from [24] \\
\hline Actor & \multicolumn{2}{|l|}{$\begin{array}{ll}\text { - } & \text { International level } \\
\text { - } & \text { National level } \\
\text { - } & \text { Provincial level } \\
\text { - } & \text { Local level }\end{array}$} & Modified from [25] \\
\hline \multirow[t]{3}{*}{ Action situation } & \multirow[t]{3}{*}{ Payment mechanism } & 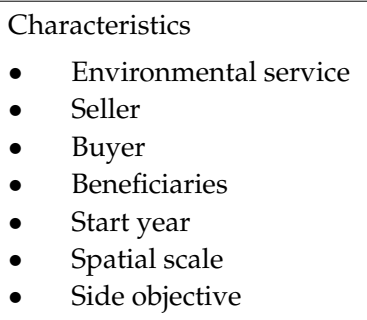 & Modified from [26] \\
\hline & & \begin{tabular}{ll}
\multicolumn{2}{l}{ Design features } \\
- & Intermediary \\
- & Seller selection \\
- & Monitoring \\
- & Sanctions \\
- & Conditionality \\
- & Baselines and scenarios \\
- & Additionality
\end{tabular} & Modified from [26] \\
\hline & & \begin{tabular}{ll}
\multicolumn{2}{l}{ Payment features } \\
- & Mode of payment \\
- & Amount \\
- & Determination of \\
& payment level \\
- & Timing of payment \\
- & Differentiation \\
- & Contract duration
\end{tabular} & Modified from $[26,27]$ \\
\hline
\end{tabular}

In this study, a qualitative and interpretative approach was applied based on textual methodsmainly, documentary review and analysis. Relevant public documents were reviewed-both international and national policy documents, guidelines, standards, instruments, acts, governmental reports, and statistical data. Secondary materials, mainly in form of books and peer reviewed journal papers, were further explored for in-depth analysis 


\section{Results}

\subsection{Physical Condition}

The Trends of Deforestation

During the colonization period, as a result of the excessive harvesting of timber in the Korean Peninsula that far exceeded the forest capacity, the average volume of timber per hectare decreased considerably [28]. The Korean War was one of the worst catastrophes of the 1950s, bringing destruction to large areas of forests to meet the demand for fuel and wood. Even after this period, forest degradation kept escalating due to unsustainable cutting and slash-and-burn cultivation [10].

In Vietnam, forestry and agriculture, the latter of which was collectivized in the 1960s and 1970s, have long been dominated by the state [29]. After the Democratic Republic of Vietnam was founded in 1954 , forest policy was aimed at the complete nationalization of the forest estate and the establishment of State Forest Enterprises (SFEs) to manage these lands [29]. SFEs were responsible for ensuring that forests were replanted and nurtured, but SFEs that exceeded planning targets were often rewarded for over-cutting, as the revenues from this sector were high [30]. In contrast, the local residents who had previously used and managed the forest lands before nationalization received little to no financial remuneration [29]. This was the reason for the underlying conflicts between locals and the state over land use over previous decades, particularly in the country's central highlands [31]. However, the central government has shifted to a market-oriented economy (known as Doi Moi), which began revising national land use law beginning in 1988. These changes allowed households to take primary responsibility for production and initiated the large-scale process of decollectivization [32].

The major causes of the deforestation and expansion of degraded forest lands of China were closely linked to several political movements and the reform of forest ownership [33]. In 1958, The Great Leap Forward focused on rapid industrial development and finally resulted in excessive logging for fuel, steel, and iron production. The Cultural Revolution from 1966 to 1976 had a massive impact on deforestation, since forestry administration was weakened nationwide [33]. Frequent tenure changes and unstable forestry policies in previous decades also inspired the over-exploitation of forest resources due to the fear that policies might change again [34]. Additionally, the increasing wood demand for economic development drove excessive logging and caused serious decreases in forest cover in many areas.

\subsection{Rules in Use}

\subsubsection{Regulatory Framework}

In South Korea, one of the earliest established legal frameworks was the Forest Law, implemented in 1961. This law promoted forest protection and development by producing a national forest plan every ten years [11]. The Erosion Control Act (1962), the Law on Voluntary Forest Guard Service (1963), the Slash and Burn Fields Act (1966), The Natural Park Act (1967), and The City Planning and Zoning Act (1971) helped bring about successful forest restoration. The first TYFR plan, backed by the president's strong support, was a community forestry program at the village level that spanned the whole country and aimed to reforest 1.0 million hectares of denuded land within 10 years [28]. Certain elements of the legal framework involved were unique. Known as "proxy execution," this legal code established the rule that if a landowner did not comply by planting trees within a certain period, the government could engage the local Village Forestry Association (VFA) to carry out the project by proxy. After planting trees, the VFA would then receive $90 \%$ of the output, and the landowner would receive only 10\% (if fruit orchards were established on the land, then the split was 80:20) [10]. This system was called "shared income" in the Forest Law, which referred to the sharing of profits gained after reforestation. 
The Vietnamese central government highly prioritized forest restoration, issuing more than 100 legal documents and many indirect regulations [35]. They also argued that these changes in the last few decades have significantly impacted the set of actors and rules governing land access and use. The most significant legal framework included: (1) The Land Law and its multiple revisions (1993, 1998, 2000, and 2001), aimed at the devolution of land use rights to private organizations and households; (2) the Law on Forest Protection and Development (1991), designed to classify land and define rules for forest protection [14]; (3) Decision 327 (1992) and Decision 661 (1998) by the prime minister, aimed at establishing two main reforestation programs; and (4) Decision 187 (1998) by the prime minister, designed to reform the SFE's organizational structure and management mechanisms [14,36]. However, some previous research has revealed that centrally-designed rules encouraged bias in forest land classification and diversions in state funding in several ways because of lack of clarity and consistency of the rules, unclear roles of SFEs, and improper monitoring at the central level [35].

In China, the environmental governance system has been dramatically developed since the 1970s [37]. Since then, the Chinese government has placed great importance on forestry. Former Premier Zhu Rongii's business tour spanned Western China in 1999, and the pilot stage of the SLCP was launched in 1999and ran to 2001. The collected data from this pilot stage helped to finalize the national plan. In 2000, the State Council provided advice for the better implementation of the pilot stages of the SLCP, which became the starting point of its implementation. Finally, the whole project was fully implemented at the end of 2002, after the announcement of advice "on further improving policy measures for [the] SLCP" and SLCP regulations. Consequently, based on the notice provided regarding the improvement of the food subsidy for the SLCP, the subsidy was changed to one of cash [37].

\subsubsection{Ownership Status and Land Use}

In 1971, more than $40 \%$ of forest lands were privately owned (national forests, $19.4 \%$; public forests, 7.4\%; and private forests, 73.2\%) [38], which caused the Korean government to pay special attention to shifting land use rights. Pursuant to "proxy execution" guidelines, about 675,000 ha (or about $25 \%$ ) of private forest land were being managed in this way by VFAs [10].

In Vietnam, land belonged to the state, while households, individuals, and organizations were allocated land for long-term agricultural, forestry, and aquaculture development purposes [14]. These rights were renewable, transferable, and inheritable, and land was essentially privatized. Forest ownership and management were mainly based on different forest classifications. Generally, protections for forests and special-use forests were governed under the unified management of the state, and very small portions of these areas were allocated to organizations, households, and individuals for management and protection [14]. The government allocated use rights for forest production and protection to different user groups, such as SFEs, management boards of protected areas (MBs), individual households, Commune People's Committees (CPC), and community and mass organizations. When China decollectivized agriculture in the late 1970s and early 1980s, the Household Responsibility Scheme (HRS) was introduced [39].

The HRS was a village-based communal land tenure system that enabled farmers to be contracted with land use rights but not rights to the land itself. Accordingly, complete ownership rights of natural resources and lands belonged to the state, while the SLCP held use and management rights during the period of the SLCP were contract only, rather than ownership rights to the land in perpetuity [25,40]. Land-users were allowed to manage and benefit from the products and services of their assigned land, based on the principle that "whoever plants maintains and benefits" [41]. In conclusion, the application of tenure has been found to differ obviously across local contexts in practice [23]. 


\subsection{Attributes of Community}

\subsubsection{Program Objectives}

In South Korea, the objectives of the first TYFR plan can be explained with four key concepts: Community participation, harmony with conservation and income, application of fast-growing species, and ceasing shifting cultivation. The government chose April as the "National Tree-Planting Period" for its campaigns, since this period is the best time to plant trees. The government encouraged various groups such as farmers, families, and students to participate in the reforestation program. Developing rural fuel wood forests and prohibiting access to the mountains substantially reduced the damage to forests. The reforestation target of 1.08 million hectares that was originally planned to be completed in 1982 was accomplished by 1978 . Additionally, 120,000 ha of devastated forestland were restored by a comprehensive erosion control project for soil conservation [28].

The 5MHRP was implemented by Decision 661, which cost about USD 2.5 billion. Among several main objectives, it had the specific goal of the community implementing efforts for poverty alleviation, hunger eradication, and the development of rural mountainous areas by creating forestry-related employment for two million people and increasing the income of people living in forest areas.

The main goal of the Chinese government's policy was that, in the program region, farmers would be allowed to voluntarily convert sloping farming lands that were unsuitable for farming into forests or grasslands, and the government would provide these farmers with free grain, cash subsidies, and free seedlings [42]. As one of the largest conservation programs in the world, the SLCP addressed both environmental and economic concerns. Additionally, with its ambitious goals of restoring forest cover through land conversion, the program also directly developed rural economies and reduced poverty in the areas where it was implemented [43].

\subsubsection{Participation Principles and Terms}

Saemaul Undong, which was initiated by former President Park, spread as a national movement. The Korean government concentrated on effectively executing its reforestation plan and related this to Saemaul Undong in the 1970s. The essence of this movement was characterized by diligence, self-help, and cooperation [1]. Participation was decided by the villagers themselves, with agreement on priorities, their potential to accomplish the projects successfully, their willingness to commit their own resources to the project, and the prospect that the project would actually increase their incomes in the near future [10]. Different kinds of support had been provided by the central government to villages or individuals by offering both financial solidified in both financial and in-kind resources (e.g., cement, bricks, steel, and seedlings), as well as low-interest loans.

Any Vietnamese households contracted regarding forest protection would receive all the products from forest thinning and non-timber products in the contracted area. However, there was little interest in participation by local authorities because the government failed to create favorable conditions [44]. While SFEs were key actors at the provincial level, implementing parts of the 5MHRP by contracting households for forest protection and production, they failed to create clear and significant changes in forest management policy. Therefore, most land released by SFEs was re-allocated to other state bodies that were eligible for state subsidies, such as the Forest Provincial Management Board (FPMB). This occurrence left most forestland under ineffective state management and many people in mountainous areas without legal access to forest resources [45].

In China, participation in the SLCP was basically voluntary. However, China had a complex system of rights regarding farmland, basically sustaining a collective land ownership system. Farmland households held use rights or residual income, while local collective groups or villages had actual ownership. Local leaders managed collective, group-maintained land ownership rights and mainly selected individual households for inclusion into the program. Since the mechanisms determining participation and implementation were complex arrangements of selection by local leaders, including 
consultation with village leaders and farm households, the program was not always voluntary at the household level [46].

\subsection{Actor}

\subsubsection{International Level}

During the implementation of restoration projects, South Korea received some international assistance from organizations like the United Nations Korean Reconstruction Agency (UNKRA) and the International Cooperation Agency (ICA), which provided food as wages for both reforestation and erosion control projects. In the mid-1960s, food aid was changed to technical assistance. The United Nations Development Program (UNDP) provided techniques for forest surveying and funding for forest resources surveys from 1964 to 1969, which was a key factor in developing the comprehensive national forest plan. The bilateral cooperation in forestry projects between South Korea and Germany that began in 1974 also contributed significantly to the progress of the country's forest management [47].

At the 5MHRP's creation, a partnership was established between Vietnam and 15 international partners. The broader Forest Sector Support Program and Partnership (FSSP\&P) was launched in 2001 as a means of supporting cooperation in the forest sector among 18 international partners and governments [48]. The FSSP\&P played a significant role in implementing official development assistance (ODA) support and capacity building. The FSSP\&P assisted the Ministry of Agriculture and Rural Development (MARD) in its work on the revised law and in implementing decrees, new strategy, and revisions of the 5MHRP, undertaking important studies, confronting gender issues in forestry, and addressing matters concerning forestry, poverty, and rural livelihoods [48]. Vietnam also joined several international conventions related to environment protection, especially focusing on the forestry sector, thus amplifying international cooperation.

The China Council for International Cooperation on Environment and Development (CCICED) was established in 1992 in China. This institution was a high-level, non-profit international advisory body consisting of top Chinese leaders and prominent international deputies such as Li Keqiang (Vice Premier of China), Zhou Shengxian (Minister of the Ministry of Environment and Protection), and Klaus Topfer (former director of the United Nations Environmental Program) [37]. The CCICED offered channels for spreading stories on successful international experiences in the environmental and developmental fields, conducted research on environment and development policies in China, and formulated policy recommendations for the top leaders of the Chinese government. Many bilateral and multilateral donor agencies also committed to provide financial aid or environmental loans to China after 1990. In summary, there were three major types of donor approaches in China: (1) The engineering approach from Japan; (2) the human development approach from the UN; and (3) the market-based approach from the World Bank [49] (Table 2).

Table 2. Different levels of actors for forest restoration.

\begin{tabular}{cccc}
\hline Category & South Korea & Vietnam & China \\
\hline International Level & UNKRA, ICA, UNDP & FSSP\&P & CCICED \\
\hline National Level & KFS & MARD & SFA, NDRC \\
\hline Provincial Level & $\begin{array}{c}\text { Forestry Dept of each } \\
\text { provincial government, } \\
\text { Police, KFS officials }\end{array}$ & $\begin{array}{c}\text { DARD, Forest Protection } \\
\text { Sub-Department }\end{array}$ & $\begin{array}{c}\text { Forestry Dept of each } \\
\text { provincial government }\end{array}$ \\
\hline Local Level & VFA, Saemaul Undong & SFEs & Local Financial Bureaus \\
\hline
\end{tabular}

\subsubsection{National Level}

In 1967, the Korea Forest Service (KFS) was established, separated from the Ministry of Agriculture and Forestry, and transferred to the Ministry of Home Affairs by presidential order in 1973. After this 
transfer, the KFS could manage Saemaul Undong and local administrative issues and strengthen forest protection using both the local government and the police [50].

The Vietnamese central government was in charge of formulating national strategies and developing implementation plans in compliance with the guidelines provided by the National Assembly and the Communist Party of Vietnam [51]. While the MARD managed the overall national forestry strategy, the Department of Forestry was responsible for sustainable forest management, forestry sector institutions, policies, planning, and monitoring [52].

In China, the State Forestry Administration (SFA) was under the State Council's direct control, with its most important task defined as drafting the overall annual plan identifying the scope, key tasks, duration, and objectives of the project, as well as the estimated level of investment and evaluation [53]. The overall plan was reviewed and approved by the Nation Development and Reform Commission (NDRC), which was examined at the ministerial level. The Office of Western Development under the State Council acted as the chief coordinator in facilitating communication between the SFA and the NDRC [37] (Table 2).

\subsubsection{Provincial Level}

The introduction of a responsibility system ensured the complete protection of forests in South Korea. One government official in authority was responsible for one village regarding the overall implementation of reforestation. Tree planting and post-management were placed under the charge of the local government (e.g., the governor, mayor, and county head), while protective control was placed under the police, and technical guidance was assigned to forestry officials.

Vietnamese provinces had the relative freedom to implement central policies within their administrative boundaries [36]. Two forest administration agencies were main actors at the provincial level and were controlled by the Provincial People's Committee (PPC). The first agency, the Department of Agriculture and Rural Development (DARD) had a forestry sub-department which operated as a specialized agency to assist the Director of the DARD in forestry activities. The second agency, the Forest Protection Sub-Department, served to advise the provinces regarding forest protection. The FPMB was also established in each locality that participated in the project. It worked as a think-tank to steer committees to implement the annual project plan [44].

Forestry departments in each provincial government of China created provincial annual plans covering the exact number of reforestation quotas requested by the province based on the overall plan from the SFA. These agencies played a role in releasing compensation in cash and grain, managing land contracts with farmers, mediating disputes, selecting and measuring land area for conversion, distributing saplings or grass species, issuing contracts, and monitoring the results of conversion [54] (Table 2).

\subsubsection{Local Level}

The VFA and the Saemaul Undong Association in South Korea were organized to reinforce reforestation activities. VFA leaders were trained to conduct reforestation activities through Saemaul Undong education programs. To encourage positive involvement in reforestation activities, the government paid fees to the people participating in village nurseries, planting, and afforestation to control erosion [55]. A unique administrative hierarchy was developed while implementing the policy. It combined both top-down and bottom-up approaches, leading to good lateral interactions between government, private, and community entities at each level [10].

Though the role of Vietnamese SFEs was limited following times of economic transition, these entities still controlled many portions of total land area in accordance with Decision 661, which implied an important role for SFEs in program implementation. SFEs simultaneously acted as sub-project managers and beneficiaries at the district/commune level.

Local Chinese financial bureaus were responsible for not only managing subsidy funding but also for compensating extra demands over fixed quotas. Household farmers were the implementers of tree 
planting, and there had been a slow start to the HRS in terms of forest management. Basically, local institutional units (Prefecture $\rightarrow$ County $\rightarrow$ Township $\rightarrow$ Village $\rightarrow$ Xiaozu $\rightarrow$ Household) reflected local capacities, resources, and uniquely crafted SLCP implementation regulations [25] (Table 2).

\subsection{Action Situation}

\subsubsection{Characteristics}

In South Korea, the TYFR plan strengthened national reforestation efforts, intensified forest protection activities, enlarged the development funds for private forest management, expanded the national forests, and conducted forest conservation projects to improve public benefits [56]. It targeted about one million hectares of the country, which was to advantage 0.5 hectares of planted area per household for 2.4 million households in rural areas [56].

The main objective of the 5MHRP was to establish five million hectares of forest, of which two million hectares would be reserved for special-use and protection forest, three million hectares would be allocated for production forest, two million hectares would be allocated for timber, non-timber forest products, and raw materials for manufacturing paper, and another one million hectares would be set aside for crops and fruit trees. The majority of farm households were given a series of financial incentives to participate in reforestation activities [57]. Though the central government tried to allocate the right of land management to either individuals or households, the government played a significant role as an endorser of forest management through the continual existence of many SFEs. SFEs controlled significant areas of the forest estate and provided most payment mechanisms as direct land managers or intermediaries, despite attempts over the past 10 years to restructure the SFEs [29]. Forest lands had been mainly managed by the state, with only one quarter of the total forest area in private households' control; the rest were held by various divisions of the state, such as SFEs, FPMBs, national parks, local governments, and armed services [58]. The government also acted as a buyer of services through business entities.

The SLCP aimed at not only protecting ecologically fragile areas but also restructuring the rural economy so that participating farmers could gradually shift to a more environmentally and economically sustainable livelihood [19]. Based on the terminology of [59], the program had public payment mechanisms that were primarily paid for by the central government, with program funds managed by the Ministry of Finance [18] (Table 3).

\subsubsection{Design Features}

Local governments in South Korea acted as intermediaries. The responsibility systems ensured that one government officer was in charge of overseeing one village with respect to the overall implementation of reforestation, and the local government could select the possible participants (either at the individual or village level) based on guidelines from the Ministry of Home Affairs. They also handled the post-management of reforestation. Protective control was placed under the guidance of the police. Technical guidance had been provided to villagers, local governors, and related forestry officials.

Funding mainly came from the Vietnamese state budget, which contributed to about $63.5 \%$ of the total budget; the rest came from credit loans, overseas funds, and self-financing [12]. The central budget went directly from the central government to the FPMB and SFEs, who were the main investment owners, whereas local people were mainly engaged and paid as laborers to perform certain activities [52]. SFEs simultaneously acted as intermediaries, sub-project managers, and beneficiaries at the district/commune level. The best quality forest lands with high timber and biodiversity value were managed by the state, while poor quality lands were distributed to households for restoration [60]. Therefore, it had a little impact on poverty alleviation and conservation outcomes. 
Table 3. Characteristics of the action situation.

\begin{tabular}{|c|c|c|c|}
\hline Category & South Korea & Vietnam & China \\
\hline $\begin{array}{l}\text { Environmental } \\
\text { services }\end{array}$ & $\begin{array}{l}\text { Conversion to forests and } \\
\text { grasslands }\end{array}$ & $\begin{array}{l}\text { Water services via forest } \\
\text { conservation and reforestation }\end{array}$ & $\begin{array}{c}\text { Targeted: Watershed protection, } \\
\text { reforestation } \\
\text { Paid for: Cropland retirement, } \\
\text { conversion to grasslands, } \\
\text { reforestation, and afforestation }\end{array}$ \\
\hline Seller & Individual, Community & Individuals, Households, SFEs & Rural households \\
\hline Buyer & Central government & Central government & Central government \\
\hline Beneficiaries & $\begin{array}{l}\text { Individuals, Households, } \\
\text { Community }\end{array}$ & Individuals, Households, SFEs & $\begin{array}{l}\text { Downstream water users and } \\
\text { timber consumers }\end{array}$ \\
\hline Initiated by & Central government & Central government & Central government \\
\hline Start year & $\begin{array}{l}\text { Initial stage 1967-1972 } \\
\text { 1st TYFR plan 1973-1978 }\end{array}$ & 1998-2010 & $\begin{array}{c}\text { Pilot 1999-2001 } \\
\text { Full scale 2002-2010 }\end{array}$ \\
\hline Spatial scale & $\begin{array}{l}\text { Targeted } 1 \text { million hectares } \\
\text { for ten years (1973-1982) }\end{array}$ & $\begin{array}{l}5 \text { million hectares } \\
\text { ( } 3 \text { million hectares of } \\
\text { production forest) } \\
\text { (2 million hectares of } \\
\text { protection forest) }\end{array}$ & 14.67 million hectares by 2010 \\
\hline Side objective & $\begin{array}{c}\text { Poverty reduction, } \\
\text { livelihood improvement, } \\
\text { economic development }\end{array}$ & $\begin{array}{l}\text { Poverty reduction, livelihood } \\
\text { improvement }\end{array}$ & Poverty reduction \\
\hline
\end{tabular}

The SLCP sustained a top-down approach, starting with retirement quotas that were distributed from the central government to provinces, continuing down to counties and townships, and finally to participating villages [18]. Based on regulations, only $20 \%$ of the counties were monitored by the central government, and 30\% of them were monitored by provincial governments. The remaining counties were monitored by county governments [61] (Table 4).

Table 4. Design Features of the action situation.

\begin{tabular}{|c|c|c|c|}
\hline & South Korea & Vietnam & China \\
\hline Intermediary & Local government & State agencies & Local government \\
\hline Seller selection & $\begin{array}{c}\text { Following guidelines made } \\
\text { by the Ministry of Home } \\
\text { Affairs }\end{array}$ & $\begin{array}{l}\text { Guidelines exist, but ad } \\
\text { hoc in reality }\end{array}$ & $\begin{array}{l}\text { Based on land slope, plot size, } \\
\text { and retired land contiguity }\end{array}$ \\
\hline Monitoring & $\begin{array}{l}\text { Post-management was } \\
\text { placed under the charge of } \\
\text { the local government, and } \\
\text { protective control under the } \\
\text { police }\end{array}$ & $\begin{array}{c}\text { Field visits, but } \\
\text { undermined by low } \\
\text { frequency and local level } \\
\text { corruption }\end{array}$ & $\begin{array}{c}\text { Frequently by village officials, } \\
\text { less by the township } \\
\text { County, and randomly by } \\
\text { upper-level government }\end{array}$ \\
\hline Sanctions & N/A & $\begin{array}{l}\text { In principle, no contract } \\
\text { renewal, but this is } \\
\text { hardly enforced }\end{array}$ & $\begin{array}{l}\text { Withholding of subsidies-but } \\
\text { weak enforcement }\end{array}$ \\
\hline Conditionality & N/A & N/A & Weak conditionality \\
\hline Baselines and scenarios & N/A & $\begin{array}{c}\text { Implicit, current } \\
\text { deforestation trends of } \\
\text { forest loss }\end{array}$ & No explicit baselines \\
\hline Additionality & N/A & Rather low & $\begin{array}{l}\text { High for land retirement; lower } \\
\text { for reforestation }\end{array}$ \\
\hline
\end{tabular}

\subsubsection{Payment Features}

The Korean government implemented different kinds of compensation for reforestation efforts, such as providing free seedlings and fertilizers under the Five-Year Fuel Wood Forest Establishment Plan from 1968 to 1972. Accordingly, the government purchased seeds that were collected from planted 
forests in cash. The households who participated in compulsory labor on plantations also received the right to collect fuel wood. Instead of cash compensation, sometimes corn and wheat flour were provided for daily compulsory labor that involved planting. These resources were mainly funded by the United States in response to Public Law 480.

Vietnamese forest lands were provided to households for restoration with very small payments for protection at around \$3.5-6.5 USD/hectares/year. However, forest payments were made regardless of what people did with the land. The poorest households often did not participate and lost contracted lands. A government report examined whether households who were contracted for forest regeneration as well as protection had the right to receive products from forest thinning, agricultural products, and non-timber products [44]. Moreover, poor families in 62 low-income districts would also be given $15 \mathrm{~kg}$ of rice per member each month during the time they were unable to feed themselves, for a maximum of seven years [44]. However, according to reports from the Center for International Forestry Research (CIFOR), the 5MHRP was characterized by rather low payment levels which could hardly compete with more profitable cash crops, although payments doubled in 2007 [12,62].

According to [19], each participating farmer who converted degraded and highly sloping cropland back to either ecological forest, economic forest, or grassland received three types of compensation: (1) An annual, in-kind subsidy of grain; (2) a cash subsidy; and (3) free saplings provided to the farmer at the beginning of the planting period. Disparities in in-kind payments were caused by the inherent differences in regional average yields [63]. Specifically, the compensation level varied according to regional average yields, with $1500 \mathrm{~kg}$ per hectare per year in the Yellow River Basin and $2250 \mathrm{~kg}$ per hectare per year in the Yangtze River Basin. The cash subsidy was 3150 CNY per hectare and 2100 CNY per hectare per year in each region. Both grain and cash subsidies would continue for eight years if ecological forests were planted, five years if economic forests were planted, and two years if grass was planted [19] (Table 5).

Table 5. Payment Features of action situations.

\begin{tabular}{|c|c|c|c|}
\hline & South Korea & Vietnam & China \\
\hline Mode of payment & Cash, In-kind & Cash, In-kind & $\begin{array}{l}\text { Cash and grain (phased out), free seedlings, and } \\
\text { technical assistance }\end{array}$ \\
\hline Amount & $\begin{array}{l}\text { Cash-purchased seeds } \\
\text { and daily labor } \\
\text { In-kind-provided corn } \\
\text { or wheat flour for daily } \\
\text { labor for planting, free } \\
\text { seedlings and fertilizers }\end{array}$ & 3-6.5 USD/Ha/year & $\begin{array}{l}\text { Cash: CNY 300/ha }(\sim \mathrm{USD} \$ 36) / \text { per year } \\
\text { Grain: Yangtze River Basin: } 2250 \mathrm{~kg} / \text { ha per year } \\
\text { Yellow River Basin: } 1500 \mathrm{~kg} / \mathrm{ha} \text { per year } \\
\text { Seedlings: CNY } 750 / \mathrm{ha} \text { (including wasteland) }\end{array}$ \\
\hline $\begin{array}{l}\text { Determination of } \\
\text { payment level }\end{array}$ & Administrative & Administrative & Depends on slopes \\
\hline Timing of payment & Daily, Weekly & Annual & Annual, normally \\
\hline Differentiation & $\begin{array}{l}\text { Depends on working } \\
\text { hours }\end{array}$ & $\begin{array}{l}\text { Higher for afforestation } \\
\text { and reforestation }\end{array}$ & Higher in Yangtze River than Yellow River Basin \\
\hline Contract Duration & Proxy execution & $1-5$ years, renewable & $\begin{array}{l}\text { Maximum of } 8 \text { years (ecological forest) } \\
\text { Maximum of } 5 \text { years (economic forest) } \\
\text { Maximum of } 2 \text { years (grassland) }\end{array}$ \\
\hline
\end{tabular}

\section{Discussion and Conclusions}

Forest restoration played significant roles under the diversified socioeconomic and natural conditions experienced in many Asian countries. Particularly in this century, South Korea, Vietnam, and China encountered dramatic forest land use changes driven by different socioeconomic and political developments, from deforestation and forest degradation to reforestation and ecological restoration. These countries have also received global attention for their institutional arrangements and incentive-based reforestation policies. This study examined the institutional settings of each country's reforestation programs, focusing on the inputs of the external factors, their effects on the relevant action arena, and their own payment mechanisms. By conducting comparisons through the guiding framework, many lessons were learned. 
South Korea, Vietnam, and China generally shared a commonality in that all major changes with respect to reforestation began in the highest levels of government, which realized its importance. For example, after a successful diagnosis of the underlying causes of deforestation, the governments of these countries established comprehensive plans to address these issues [11]. In South Korea, the scarcity of fuel wood among rural people was caused by the excessive and massive cutting that occurred during colonization and the Korean War. It also resulted in many social and environmental problems, inspiring the central government to establish state-led forest restoration projects in the late 1960s and early 1970s, initiated by the president. As explained above, the highest levels of government recognized the value of domestic forests as well as the environmental and economic problems that were caused by deforestation and forest degradation. Increased education, training, and scientific research and development contributed to the adoption of more sustainable approaches. Raising awareness of forests' roles as protectors of watersheds that feed agricultural and urban areas and foster biodiversity has been actively promoted by governments. The Korean case clearly shows the political will, financial resources, and the engagement of local communities were all mobilized properly to achieve a common goal [64]. Additionally, forests have tended to take on greater national, cultural, and spiritual meaning. In Vietnam, deforestation resulted from the increasing scarcity of wood needed by the growing timber industry, along with economic transition. Since the Vietnamese economy is critically dependent on the watershed services provided by forests, the value of forests has been strongly promoted by the central government through large-scale restoration projects. In China, due to the massive damage resulting from devastating floods in 1998 that were associated with deforestation, the central government initiated the SLCP and implemented a series of regulations.

Rules of use, described as appropriate legislation and land tenure reform in the framework, also played an important role in restoration. In South Korea, unlike China and Vietnam, the proportion of private forests was significantly higher than that of public forests, so the central government encouraged private owners to reforest their land by enacting a law providing for "proxy execution." Land owners could choose to either reforest the land themselves or let it be reforested and managed by VFAs in exchange for a percentage of the output. Due to major shifts in policies in terms of forest tenure reform, the government intensified its efforts and established various forms of usage rights for forest dwellers that played an important role in motivating participation. In Vietnam, forest land allocation has been fully implemented by the central government, and usage rights are renewable, transferable, and inheritable, making the land essentially privatized. In China, as a result of the decollectivized agriculture of the late 1970s and early 1980s, the HRS and forest tenure reform was introduced. The HRS is a village-based communal land tenure system in which farmers may contract for land use rights but not rights to the land itself. The core idea behind this system is that "Whoever plants maintains and benefits" [41]. Subsequently, timber markets were opened to allow communities to negotiate sales and purchases of wood [10].

In successful reforestation projects, various levels of actors played considerable roles. Regarding the country-wide cases examined here, the importance of international-level cooperation cannot be over-emphasized. South Korea received international financial assistance that provided food as wages for both reforestation and erosion control projects. South Korea also received instruction in forest conservation techniques, which contributed to the progress of the country's capacity-building concerning forest management. In Vietnam, the central government enthusiastically sought support from the international community for forest restoration. A special partnership was established with international partners as a means of cooperation in the forest sector, and it has played a significant role in implementing the policy and building capacity. In China, many bilateral and multilateral donor agencies have also committed to provide financial aid or environmental loans to China since the 1990s. Similarly, national- and local-level actors' contributions have been important. By sharing a vision of short- and long-term benefits, local governments and communities were encouraged to actively participate in the program. Clear guidelines and relevant laws should be developed with respect to 
each local situation. As experienced in recent Asian success cases, institutional arrangements and clearer ownership are needed for greater community participation [65].

An action situation was defined as a payment mechanism in the study and was further described as involving general characteristics, design, and payment features. The three cases discussed above illustrated that sellers and, thus, beneficiaries were individuals and local communities who were directly influenced by reforestation efforts. In addition, the central governments were the initiators of the programs, as well as the buyer of the environmental services accrued from reforestation. To promote the sustainability of the reforestation policy, a special forestry fund was established which supported rural households with both cash and in-kind payments. In South Korea, a fund was established by the national treasury and was distributed not only for implementing forest restoration by the central government but also for providing loans to individual foresters. The budget shortage for the wood for fuel project was to be solved by a special allocation from the reserve funds [33]. Vietnam also launched the 5MHRP fund through the Forest Sector Support Partnership in cooperation with international donors, which helped to sustain the program while implementing its policies. China established the Eco-Compensation fund for project implementation outside the scope of the higher budget allocated by the central government for forestry during the restoration project's implementation period. It should be noted that reward (cash and in-kind payments) and voluntarism are both important factors, as they help participants understand the benefits and consequences when they fulfil and/or fail to comply with agreed rules [66]. A recent study for Vietnam case shows, however, the a payment system can be susceptible to distributional risk, resulting in the rich getting most [67]. This illustrates the highly organized institutional complexity of the inspection and monitoring system that is required for the efficient implementation of programs [68].

This study is expected to provide a contribution to the literature on national-scale forest restoration by utilizing a relevant framework. The ability of nations that have implemented restoration programs to restore their forests is often influenced by external variables, including local biophysical conditions, local community attributes, and local, state, and federal rules. Each nation should carefully design and implement appropriate policies for actors as well as payment mechanisms. While these findings may not be readily applicable and transferable to other regions and countries, it is hoped that they will help to inform nations about how these variables affect decision-making and resource allocation and ultimately facilitate successful forest restoration.

Author Contributions: Conceptualization, G.C. and S.-i.K.; methodology, G.C.; software, G.C. and Y.J.; validation, G.C. and S.-i.K.; formal analysis, G.C.; investigation, G.C.; resources, G.C. and Y.J.; data curation, G.C. and Y.J.; writing—original draft preparation, G.C.; writing—review and editing, Y.J.; visualization, G.C. Y.J.; supervision, S.-i.K.; project administration, G.C. and S.-i.K.

Funding: This research received no external funding.

Conflicts of Interest: The authors declare no conflict of interest.

\section{References}

1. The Food and Agriculture Organization (FAO). Global Forest Resources Assessment 2015; FAO: Rome, Italy, 2016.

2. The Food and Agriculture Organization (FAO). The State of the World's Forests 2018 - Forest Pathways to Sustainable Development; FAO: Rome, Italy, 2018.

3. The International Union for Conservation of Nature (IUCN). Deforestation and Forest Degradation, in Issues Brief; IUCN: Gland, Switzerland, 2017.

4. The International Union for Conservation of Nature (IUCN); International Tropical Timber Organization. The Forest Landscape Restoration Handbook; Earthscan: London, UK, 2007.

5. Crawford, S.E.S.; Ostrom, E. A grammar of institutions. Am. Political Sci. Rev. 1995, 89, 582-600. [CrossRef]

6. Imperial, M.T.; Yandle, T. Taking institutions seriously: Using the IAD framework to analyze fisheries policy. Soc. Nat. Resour. 2005, 18, 493-509. [CrossRef] 
7. Matesaert, H. Institutional Analysis in Natural Resources Research. In Socio-Economic Methodology for Natural Resources Research. Best Practice Guidelines; Natural Resources Institute, The University of Greenwich: Chatham, UK, 2002.

8. Clement, F.; Amezaga, J.M.; Orange, D.; Calder, I.R.; Large, A.R.G.; Toan, T.D. Linking reforestation with forest policies: A multi-scale and interdisciplinary methodology applied to Vietnam. Int. Assoc. Study Commons 2008, 1-28. Available online: http://dlc.dlib.indiana.edu/dlc/bitstream/handle/10535/2263/Clement_ 108301.pdf?sequence=1\&isAllowed=y (accessed on 25 June 2019).

9. KFS. Korea Forest Service. 2013. Available online: http://english.forest.go.kr/newkfsweb/html/EngHtmlPage. do?pg=/english/korea/korea_010_010.html\&mn=ENG_02_01_01 (accessed on 25 June 2019).

10. Gregersen, H.; El Lakany, H.; Bailey, L.; White, A. The Greener Side of REDD+: Lessons for REDD+ from Countries Where Forest Area Is Increasing; Rights and Reources Initiative: Washington, DC, USA, 2011.

11. Korea Forest Service (KFS). Lessons Learned from the Republic of Korea's National Reforestation Programme; KFS: Deajeon, Korea, 2014.

12. Wertz-Kanounnikoff, S.; Kongphan-Apirak, M. Reducing Forest Emissions in Southeast Asia: A Review of Drivers of Land-Use Change and How Payments for Environmental Services (PES) Schemes Can Affect Them; Center for International Forestry Research (CIFOR): Bogor, Indonesia, 2008.

13. McElwee, P. Reforesting "Bare Hills" in Vietnam: Social and Environmental Consequences of the 5 Million Hectare Reforestation Program. Ambio 2009, 38, 325-333. [CrossRef] [PubMed]

14. The, B.D.; Ngoc, H.B. Payments for Environmental Services in Vietnam: Assessing an Economic Approach to Sustainable Forest Management; Economy and Environment Program for Southeast Asia (EEPSEA): Los Baños, Philippines, 2006.

15. Organization for Economic Co-operation and Development (OECD). Mainstreaming Biodiversity for Sustainable Development; OECD: Paris, France, 2018.

16. Khoi, T.V. Five Million Hectare Reforestation Program (1998-2010). 2014. Available online: https://www.slideshare.net/CIFOR/five-million-hectare-reforestation-program-1998-2010?qid=d59c8d7db1d7-4db2-bcb2-f35430b970fd\&v=\&b=\&from_search=1 (accessed on 25 June 2019).

17. Xu, J.; White, A.; Lele, U. China's Forest Tenure Reforms; The Rights and Resources Initiative: Washington, DC, USA, 2010.

18. Bennett, M.T. China's sloping land conversion program: Institutional innovation or business as usual? Ecol. Econ. 2008, 65, 699-711. [CrossRef]

19. Xu, Z.; Bennett, M.T.; Tao, R.; Xu, J. China's Sloping Land Conversion Program four years on: Current situation and pending issues. Int. For. Rev. 2004, 6, 317-326. [CrossRef]

20. Cheng, B.; Clue, S. Forestry in Asia-Issues for Responsible Investors; Responsible Research: Singapore, 2010.

21. McGinnis, M.D. An introduction to IAD and the language of the Ostrom workshop: A simple guide to a complex framework. Policy Stud. J. 2011, 39, 169-183. [CrossRef]

22. Koontz, T.M. An introduction to the institutional analysis and development (IAD) framework for forest management research. In Unpublished Manuscript Prepared for the "First Nations and Sustainable Forestry: Institutional Conditions for Success" Workshop; University of British Columbia: Vancouver, BC, Canada, 2003.

23. Scherr, S.J.; Bennett, M.T.; Loughney, M.; Canby, K. Developing Future Ecosystem Service Payments in China: Lessons Learned from International. Available online: http://citeseerx.ist.psu.edu/viewdoc/download?doi= 10.1.1.463.9413\&rep=rep1\&type=pdf (accessed on 25 June 2019).

24. Grant, A. A study of the implementation of China's sloping land conversion policy 'Tui Geng Huan Lin': A case study-Hanyuan conty, Sichuan province. For. Trees Livelihoods 2003, 13, 331-343. [CrossRef]

25. Kolinjivadi, V.; Sunderland, T. A review of two payment schemes for watershed services from China and Vietnam: The interface of government control and PES theory. Ecol. Soc. 2012, 17, 10. [CrossRef]

26. Wunder, S.; Engel, S.; Pagiola, S. Taking stock: A comparative analysis of payments for environmental services programs in developed and developing countries. Ecol. Econ. 2008, 65, 834-852. [CrossRef]

27. Porras, I.T.; Grieg-Gran, M.; Neves, N. All That Glitters: A Review of Payments for Watershed Services in Developing Countries; IIED: London, UK, 2008.

28. The Food and Agriculture Organization (FAO). Asia and the Pacific: National Forest Programmes Update 34; FAO: Rome, Italy, 2000.

29. McElwee, P.D. Payments for environmental services as neoliberal market-based forest conservation in Vietnam: Panacea or problem? Geoforum 2012, 43, 412-426. [CrossRef] 
30. Ogle, A.; Blakeney, K.J.; Hoe, H. Natural Forest Management Practices; Asian Development Bank: Hanoi, Vietnam, 1998.

31. Salemink, O.H.J.M. Vietnam: Indigenous Minority Groups in the Central Highlands (Writenet Report 5/2001); UN High Commissioner for Refugees, Centre for Doc. \& Res: Geneva, Switzerland, 2002.

32. Kerkvliet, B.J.T. Village-state relations in Vietnam: The effect of everyday politics on decollectivization. J. Asian Stud. 1995, 54, 396-418. [CrossRef]

33. Chokkalingam, U. Learning Lessons from China's Forest Rehabilitation Efforts-National Level Review and Special Focus on Guangdong Province; CIFOR: Jakarta, Indonesia, 2006.

34. Dachang, L. Rehabilitation of Degraded Forests to Improve Livelihoods of Poor Farmers in South China; CIFOR: Jakarta, Indonesia, 2003.

35. Clement, F.; Amezaga, J.M. Afforestation and forestry land allocation in northern Vietnam: Analysing the gap between policy intentions and outcomes. Land Use Policy 2009, 26, 458-470. [CrossRef]

36. Clement, F.C. A Multi-Level Analysis of Forest Policies in Northern Vietnam: Uplands, people, Institutions and Discourses. Ph.D. Thesis, University of Newcastle upon Tyne, Newcastle upon Tyne, UK, 2008.

37. Jia, G. Policy Learning and Policy Implementation in China. Ph.D. Thesis, The University of Hongkong, Hongkong, China, 2010.

38. Korea Forest Service (KFS). Korea Forestry Statistics (No. 5); KFS: Deajeon, Korea, 1972.

39. Lohmar, B. Feeling for stones but not crossing the river: China's rural land tenure after twenty years of reform. Chin. Econ. 2006, 39, 85-102. [CrossRef]

40. China.org.cn. Law of the People's Republic of China on Land Contract in Rural Areas. 2011. Available online: http://www.china.org.cn/china/LegislationsForm2001-2010/2011-02/12/content_21907969.htm (accessed on 25 June 2019).

41. Li, X.; Jin, L.; Zuo, T. Payment for Watershed Services in China: Role of Government and Market, a Diagnostic Study. In Proceedings of the 2nd International Conference on: Sustainable Sloping Lands and Watershed Management: Linking Research to Strengthen Upland Policies and Practice, Luang Prabang, Laos, 12-15 December 2006.

42. Sun, C.; Liqiao, C. A Study of Policies and Legislation Affecting Payments for Watershed Services in China; Research Center of Ecological and Environmental Economics Beijing: Beijing, China; International Institute for Environment and Development: London, UK, 2006.

43. Trac, C.J.; Harrell, S.; Hinckley, T.M.; Henck, A.C. Reforestation programs in Southwest China: Reported success, observed failure, and the reasons why. J. Mt. Sci. 2007, 4, 275-292. [CrossRef]

44. The Priestly Fraternity of Saint Peter (FSSP). On the Implementation Result of the Five Million Hectare New Afforestation Project and the Forest Protection and Development Program in the 2011-2020 Period; FSSP: Hanoi, Vietnam, 2011.

45. The World Bank Group (WB). Soicalist Republic of Vietnam: Forest Law Enforcement and Governance; WB: Washington, DC, USA, 2010.

46. Lohmar, B.; Nickerson, C.; Uchida, E.; Xu, J. Land Conservation in the United States and China: A Comparison of Practices, Policies, and Data Implications for Assessment and Evaluation. In Proceedings of the Presentation at the Fourth International Conference on Agricultural Statistics, Beijing, China, 22 October 2007.

47. KFS. Forestry Techinical Cooperation between Korea and Germany. 2019. Available online: http://theme. archives.go.kr/next/forest/project/internationalCooperationStep02.do (accessed on 25 June 2019).

48. United Nations Forum on Forests (UNFF). National Report to the Fifth Session of the United Nations Forum on Forests (Viet Nam); UNFF: New York, NY, USA, 2005.

49. Morton, K.X. International Aid and China's Environment: Taming the Yellow Dragon; Routledge: London, UK, 2005.

50. Lee, K.-J. Successful Reforestation in South Korea: Strong Leadership of Ex-President Park Chung-Hee; Lee Kyung-Joon: Seoul, Korea, 2013.

51. The Ministry of Agriculture and Rural Development (MARD). Five Million Hectare Reforestation: Sythesis Report; MARD: Hanoi, Vietnam, 2001.

52. van der Poel, P. Towards A Program-Based Approach in the Forest Sector in Viet Nam; GFA Consulting: Hanoi, Vietnam, 2007; Volume 661. 
53. China State Council. Regulation on Land Conversion from Farmland Back to Forestland; China State Council: Beijing, China, 2002.

54. Weyerhaeuser, H.; Wilkes, A.; Kahrl, F. Local impacts and responses to regional forest conservation and rehabilitation programs in China's northwest Yunnan province. Agric. Syst. 2005, 85, 234-253. [CrossRef]

55. The Food and Agriculture Organization (FAO). Integrated Policy for Forests, Food Security and Sustainable Livelihoods-Lessons from the Republic of Korea; FAO: Rome, Italy, 2016.

56. Korea Forest Service (KFS). Korea Forest Policy during Last 50 Years; Korea Forest Service: Deajeon, Korea, 1997.

57. Huong, T.T.T.; Zeller, M.; Hoanh, C.T. The 'Five Million Hectare Reforestation Program'in Vietnam: An Analysis of its Implementation and Transaction Costs-A Case Study in Hoa Binh Province. Q. J. Int. Agric. 2014, 53, 341-375.

58. The Priestly Fraternity of Saint Peter (FSSP). Vietnam Forest Sector Indicators and 2005 Baseline Data Report; FSSP: Hanoi, Vietnam, 2007.

59. Wunder, S. Payments for Environmental Services: Some Nuts and Bolts; Center for International Forestry Research: Bogor, Indonesia, 2005.

60. Thuan, D.D. Forestry, Poverty Reduction and Rural Livelihoods in Vietnam; Ministry of Agriculture and Rural Development: Hanoi, Vietnam, 2005.

61. State Forestry Administration (SFA). Notice on Measures for Monitoring and Acceptance Testing of the Sloping Land Conversion Program; SFA: Beijing, China, 2001.

62. Liss, B.M. Development and Application of A Pilot Policy on Payment for Environmental Services (PES) in Da River Basin, Son La Province; Consultant Report to the Vietnamese-German Forestry Programme, International Consultancy Services: Landsberg/Lech, Germany, 2008.

63. Uchida, E.; Xu, J.; Rozelle, S. Grain for green: Cost-effectiveness and sustainability of China's conservation set-aside program. Land Econ. 2005, 81, 247-264. [CrossRef]

64. Allison, H. The Fall and Rise of South Koreas Forests by Hilary Allison. Q. J. For. 2016, 110, $37-41$.

65. Appanah, S. Forest Landscape Restoration for Asia-Pacific Forests; FAO/RECOFTC: Bangkok, Thailand, 2016.

66. Zhang, K.; Artati, Y.; Putzel, L.; Xie, C.; Hogarth, N.J.; Wang, J.N.; Wang, J. China's Conversion of Cropland to Forest Program as a national PES scheme: Institutional structure, voluntarism and conditionality of PES. Int. For. Rev. 2017, 19, 24-36. [CrossRef]

67. Duong, N.T.B.; Groota, W.T.d. Distributional risk in PES: Exploring the concept in the Payment for Environmental Forest Services program, Vietnam. For. Policy Econ. 2018, 92, 22-32. [CrossRef]

68. Putzel, L.; Baral, H.; Zhang, K.; Artati, Y.; Cronkleton, P. Studies on forest landscape restoration in hilly and moun-tainous regions of Asia and Africa-An introduction to the Special Issue. Int. For. Rev. 2017, 19, 1-7. 